\title{
INVESTIGATION OF REFUELING STATIONS INFLUENCE ON URBANIZED ENVIRONMENT WITH THE HELP OF PRECIPITATION BIOTESTING
}

The problem of refueling stations construction within residential districts of a city is currently the object of considerable attention in present publication. Results of atmospheric precipitation biotesting taken on the territory of refueling stations within the residential districts and beyond the city were analyzed.

Розглянуто проблему будівництва автозаправних станиій у житлових районах міста. Наведено результати біотестування атмосферних опадів, відібраних на територї̈ автозаправних станцій у житлових районах міста та поза межами міста.

biotesting, emissions, precipitation, refueling stations, residential area, standard deviation of roots and stems length, structure fluctuations

\section{Introduction}

Development of modern urbanized territories connects closely with the rapid increasing of autotransport quantity. In turn it causes growth of refueling stations net, because of large amount of autotransport needs large volumes of fuel. Today a great deal of ecologists trouble such fact as the increasing of refueling stations quantity that are constructed in the dwelling districts of a city, in spite of the fact that building these dangerous objects in above-mentioned zones is forbidden according to some state sanitary rules.

On the territory of refueling stations there is volatilization of oil products as a result of storage reservoir filling, daily temperature change (so-called corresponding large and small breathing) and autotransport refueling process. Pollution caused by stationary sources, that are located on the territory of refueling stations, is supplemented with cars exhausted emissions. Exhausted gases include more than 200 different compounds, among which are mutagen, carcinogen namely: benzpyren, xylene, formaldehyde, benzene, heavy metals and so on [1]. If refueling station is constructed within a city, especially in zone of compact built-up area, then the walls of constructions serve as screens and lack of territory ventilation. Moreover pollutants, produced both by stationary and non stationary sources, are concentrated in the breathing zone. Thus additional local pollution of the environment occurs in such case.

Complex ecotoxicological loading on the environment when refueling stations are located within city boundaries, adding intensive traffic, are reasons of biochemical abnormality appearing that may be dangerous for all living organisms, including people.

(C) Tetiana I. Bilyk, Olga S. Shtyka, 2009

\section{Analysis of researchers and publications}

Pollution of the environment near refueling stations and highways is investigated in a great deal of recent publications $[1 ; 2 ; 3 ; 4 ; 5]$. In previously mentioned works, mainly investigation concerning determination of heavy metals concentration in soils $[1 ; 3 ; 4]$ and general assessment of possible negative influence of highways and refueling objects are represented [2]. Also information concerning investigation of soil toxicity near refueling stations with the help of biotesting is given in publication [5].

\section{Purpose}

The purpose is to investigate influence of refueling stations on the environment in the zones of residential compact built-up areas and beyond a city with the help of biotesting of precipitation (in this case snow), and to estimate general toxicity of the environment. The task is to draw a conclusion concerning safety of refueling station location within city boundaries, especially in built-up areas and dwelling districts.

\section{Practical part}

Refueling stations are objects of service that cause significant pollution of all but spheres of the environment namely atmosphere, hydrosphere, upper layers of lithosphere over close mutual interaction between each other.

Consequently it was decided to investigate toxicity of chemical composition of atmospheric precipitation (in this case snow) as a derivative of atmospheric air content with which they interact from one side. And from other side snow layer accumulates pollutants that are present in air and after melting chemicals may penetrate into soils. Thus atmospheric precipitation serve as factual indicator of air pollution and soil [6]. 
Highways may be also considered as a source of the environment pollution not less than refueling stations, because of transport traffic causes additional pollution of the adjacent territory that's why it was necessary to take into account intensity of traffic. Thus the beginning stage of investigation was choice of refueling stations on the territory of which precipitation was sampled according to such parameters: intensity of traffic, quantity of served cars and lorries.

The samples were taken on the different distances $(0,10$ and $15 \mathrm{~m})$ from pollution source. The samples represented five-day lying snow.

The investigation was made by biotesting method applyed. A criterion of toxicity within biotesting is evaluated as inhibiting of roots growth and survival of biotesters [7;8]. Proposed test-object was lettuces Lactuca sativa L. Biotest analyzes roots and stems growth and estimates early stages of growth and survivorship rate [7].

Investigation was fulfilled in Petri dishes. First of all each was covered with double layer of filtering paper. Then near $5 \mathrm{ml}$ of every investigated sample of atmospheric precipitation was carried in separate double-dishes. Lettuces seeds that were selected for test, had the same form, color and size. Quantity of seeds in one Petri dish was equal to 25.

Duration of incubation period was five days at temperature $22-23^{\circ} \mathrm{C}$.

Potable water was used as medium for control, because it has standardization. Possible surplus of iron, calcium and magnesium, chlorine, that may presented in tap water, was removed using filter [7]. Also $\mathrm{pH}$ level of potable water was measured and it was equal to 7 that corresponds to standard GOST 2874-82 [9].

After incubation period amount of grown seeds and size of roots and stems were measured whereupon standard deviation of roots and stems length for each sample was calculated. As standard deviation in investigated samples exceeded control value in two times, it was obligatory to repeat experiment with purpose to confirm received data.

\section{Investigation results}

In control samples plants grew relatively quickly in comparison with plants that grew in investigated samples of melting snow in both cases (tab. 1).
Amount of sprouted plants is the same almost in all samples, including control, but there are deviations in size and structure of plants stems and roots. Comparing biotesting results of snow that was taken near refueling stations in zone of compact built-up area and snow that was taken near refueling stations beyond city, it is important to underline that first mentioned snow samples have worse results namely: less percentage of plant-biotesters' sprouting and higher value of standard deviation of roots and stems length (tab. 1).

Table 1

Results of snow biotesting, sampled near refueling stations

\begin{tabular}{|c|c|c|c|}
\hline \multirow[t]{2}{*}{$\begin{array}{l}\text { Type of } \\
\text { sample }\end{array}$} & \multirow[t]{2}{*}{ Sprouting, \% } & \multicolumn{2}{|c|}{$\begin{array}{c}\text { Standard deviation } \\
\text { of length }\end{array}$} \\
\hline & & root & stem \\
\hline \multicolumn{4}{|c|}{ Residential built-up area } \\
\hline Control & 100 & 4,3 & 3,1 \\
\hline 0 & 90 & 9,6 & 4,9 \\
\hline 10 & 92 & 12,1 & 6,7 \\
\hline 15 & 92 & 14,4 & 4,5 \\
\hline \multicolumn{4}{|c|}{ A city } \\
\hline Control & 100 & 4,3 & 3,1 \\
\hline 0 & 91 & 7,0 & 3,3 \\
\hline 10 & 94 & 9,5 & 3,9 \\
\hline 15 & 92 & 7,1 & 3,8 \\
\hline
\end{tabular}

Thus the inhibiting of roots development is evidence of fact that medium is toxic. As composition of precipitation is considered as derivative of air content, consequently atmospheric air is classified as significantly polluted.

Besides such indicators like sprouting and standard deviation, it was investigated also morphological structure changes in both cases. Thus in control samples plants did not have structure sprouts deviations in comparison with plants that grew in investigated samples of melting snow in both cases (tab. 2).

Table 2

Morphological structure changes of biotesters that grew in atmospheric precipitations, sampled near refueling stations

\begin{tabular}{|l|c|c|c|}
\hline \multirow{2}{*}{$\begin{array}{l}\text { Type } \\
\text { sample }\end{array}$} & Structure sprouts deviations, \% \\
\cline { 2 - 4 } & $\mathrm{a}^{*}$ & $\mathrm{~B}^{*}$ & $\mathrm{c}^{*}$ \\
\hline \multicolumn{4}{|c|}{ Residential built-up area } \\
\hline Control & - & - & - \\
0 & 20 & 20 & 36 \\
10 & 8 & 24 & 32 \\
15 & 16 & 12 & 32 \\
\hline \multicolumn{5}{|c|}{ A city } \\
\hline Control & - & - & - \\
0 & 15 & 20 & 16 \\
10 & 10 & 22 & 14 \\
15 & 7 & 12 & 12 \\
\hline
\end{tabular}

*a - furcation of root and stem, b- furcation of root; $\mathrm{c}-$ bending of root. 
The dominant changes in plants-biotesters structure were furcation of root, furcation of root and stem, and the bending of root. In spite of the fact that all these structure fluctuations were common for all investigated samples of melting snow, such deviations manifested more intense in the samples taken near refueling station in dwelling districts (tab. 2).

Thus structure fluctuations of roots and stems may be also evidence that medium where seeds of lettuces Lactuca sativa L sprouted may be defined like toxic. Taking into consideration the fact that composition of precipitation is considered as derivative of atmospheric air content, thus it should be suggested as polluted.

\section{Conclusion}

1. Inhibiting roots and stems development and structural changes are evidence that medium is toxic. As composition of precipitation is derivative from air content, consequently atmospheric air is classified as significantly polluted in both cases.

2. Snow samples that were taken near refueling stations in zone of compact built-up area snow samples have worse results like less percentage of plant-biotesters sprouting and higher value of standard deviation of roots and stems length.

3. Thus it is possible to suppose that in the case of refueling stations in zone of compact built-up area and dwelling districts local pollution level of the environment is rather higher and pollutants are not disperse via lack of territory ventilation and walls screening.

4. In such way construction of refueling stations in the zones of compact built-up areas and residential districts is rather dangerous in respect to complex, long-term and accumulating character of such pollution.

\section{References}

1. Ибрагимова Э.Э. Экологическая и фитотоксикологическая оценка загрязнения сельскохозяйственных почв Крыма пестицидами и солями тяжелых металлов/ Э.Э. Ибрагимова, Д.В. Баличиева, Э.Р. Алиев // Екологія і ноосфера. - 2006. - Т.17, № 3-4. - С. 21-29.

2. Желновач А.Н. Уровень воздействия автомобильной дороги на окружающую среду (придорожное пространство)/ А.Н. Желновач // Матеріали Х Всеукр. наук. конф. студентів, магістрів і аспірантів «Екологічні проблеми регіонів». Одеса, 21-25 квіт. 2008 р. - О.: Одес. держ. еколог. ун-т., 2009. - С. 92-93.

3. Шейкіна О.Ю. Екологічна оцінка забруднення міських грунтів важкими металами вздовж основних транспортних магістралей міста Черкаси / О.Ю. Шейкіна, О.О. Мислюк // Екологія довкілля та безпека життєдіяльності. - 2008. - №1. - С. 61-65.

4. Біланич M.M. Свинець, кобальт і цинк у грунтах Закарпатської області/ М.М. Біланич, В.І. Ніколайчук // Екологія довкілля та безпека життєдіяльності. - 2008. №3. - C. 19-26.

5. Штика О.С. Токсикологічна оцінка земель, забруднених викидами АЗС за рослиннами біотестерами/ О.С. Штика, А.О. Авдєєва, Т.І. Білик // Матеріали II Міжнародної наук.-техн. конф. «Проблеми хімотології». - К.: Кн. Вид-во НАУ, 2008. - 230-231 c.

6. Маджд С.М. Оцінка забруднення атмосфери через біотестування атмосферних опадів / C.M. Маджд, Г.М. Франчук // Матеріали Х Всеукр. наук. конф. студентів, магістрів і аспірантів «Екологічні проблеми регіонів». - О.: Одес. держ. еколог. ун-т., 2009.- 182 с. 7. Арсан O.M. Методи гідроекологічних досліджень поверхневих вод / О.М. Арсан, О.А. Давидов, Т.М. Дьяченко / Пр. Ін-ту гідробіології НАН України. К.: ЛОГОС. - Вип.1. - 2006. - 408 с.

8. Кіпніс Л.С. Біотестування якості води озер міської зони Києва / Л.С. Кіпніс, Ю.М. Ситник, І.М. Коновець // Наукові записки.-2001.-№3(14). - С. 198-199.

9. Запольський А.К. Водопостачання, водовідведення та якість води: підруч. для студентів вищих навчальних закладів / А.К. Запольський. - К.: Вища шк., 2005. - Вип.1. - 671 с. 